\title{
Predicting the effect of salt on heat tolerance of Listeria monocytogenes in meat and fish products
}

\author{
Abdalas, Somaya; Al-Hilali, Iman; Hansen, Tina Beck
}

Publication date:

2019

Document Version

Publisher's PDF, also known as Version of record

Link back to DTU Orbit

Citation (APA):

Abdalas, S., Al-Hilali, I., \& Hansen, T. B. (2019). Predicting the effect of salt on heat tolerance of Listeria monocytogenes in meat and fish products. Poster session presented at 11th International Conference on Predictive Modelling in Food, Braganza, Portugal.

\section{General rights}

Copyright and moral rights for the publications made accessible in the public portal are retained by the authors and/or other copyright owners and it is a condition of accessing publications that users recognise and abide by the legal requirements associated with these rights.

- Users may download and print one copy of any publication from the public portal for the purpose of private study or research.

- You may not further distribute the material or use it for any profit-making activity or commercial gain

- You may freely distribute the URL identifying the publication in the public portal

If you believe that this document breaches copyright please contact us providing details, and we will remove access to the work immediately and investigate your claim. 


\section{Predicting the effect of salt on heat tolerance of Listeria monocytogenes in meat and fish products}

Somaya Abdalas, Iman Al-Hilali and Tina Beck Hansen (tibha@food.dtu.dk)

DTU Food, Division for Microbiology and Production, Research Group for Food Microbiology and Hygiene

Listeria monocytogenes is a potentially fatal foodborne pathogen that can be found in various food products, including meats. It can tolerate adverse conditions such as high salt concentrations, thus, the elimination of the organism is difficult in food processing. This study was conducted to enable prediction of the effect of salt on heat tolerance of $L$. monocytogenes in food. The obtained model enables food processors to design proper thermal processes to eliminate $L$. monocytogenes in meat products to ensure safety and prevent foodborne listeriosis.

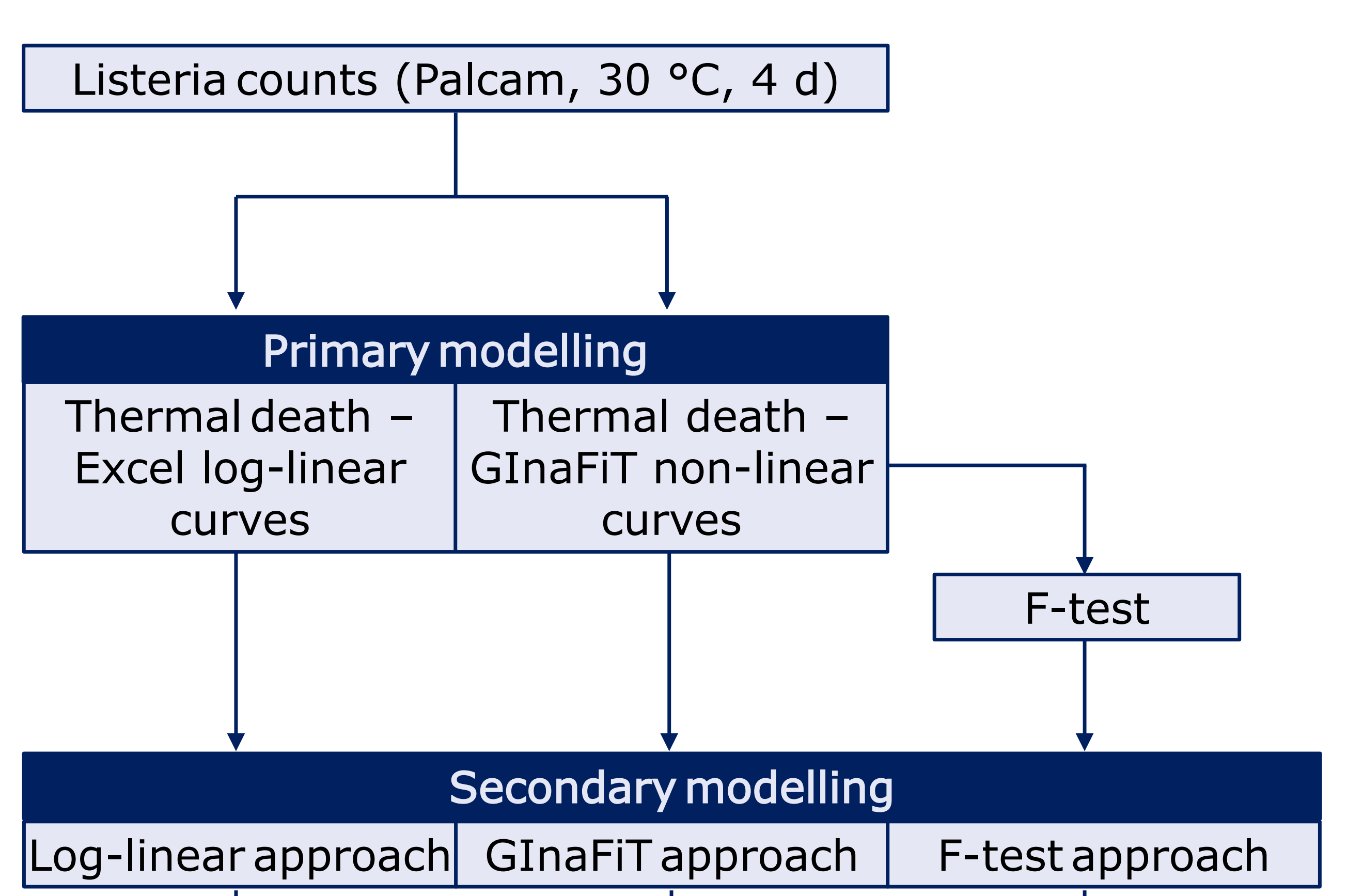

Log-linear approach GInaFiT approach F-testapproach

Selection of best approach (lowest RSS)

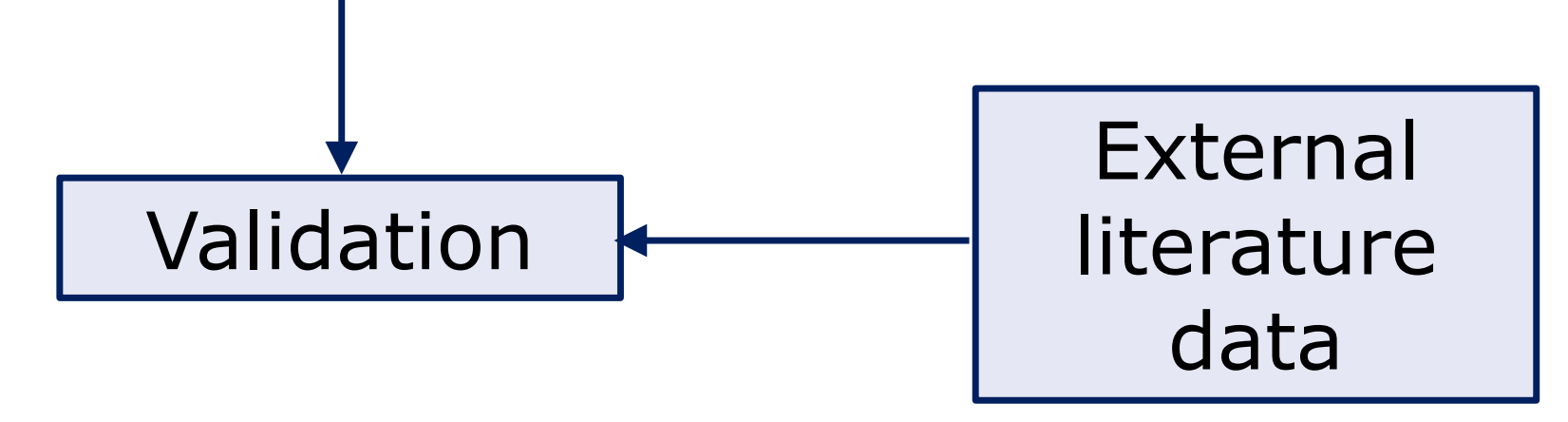

Figure 1. Overview of modelling procedire.

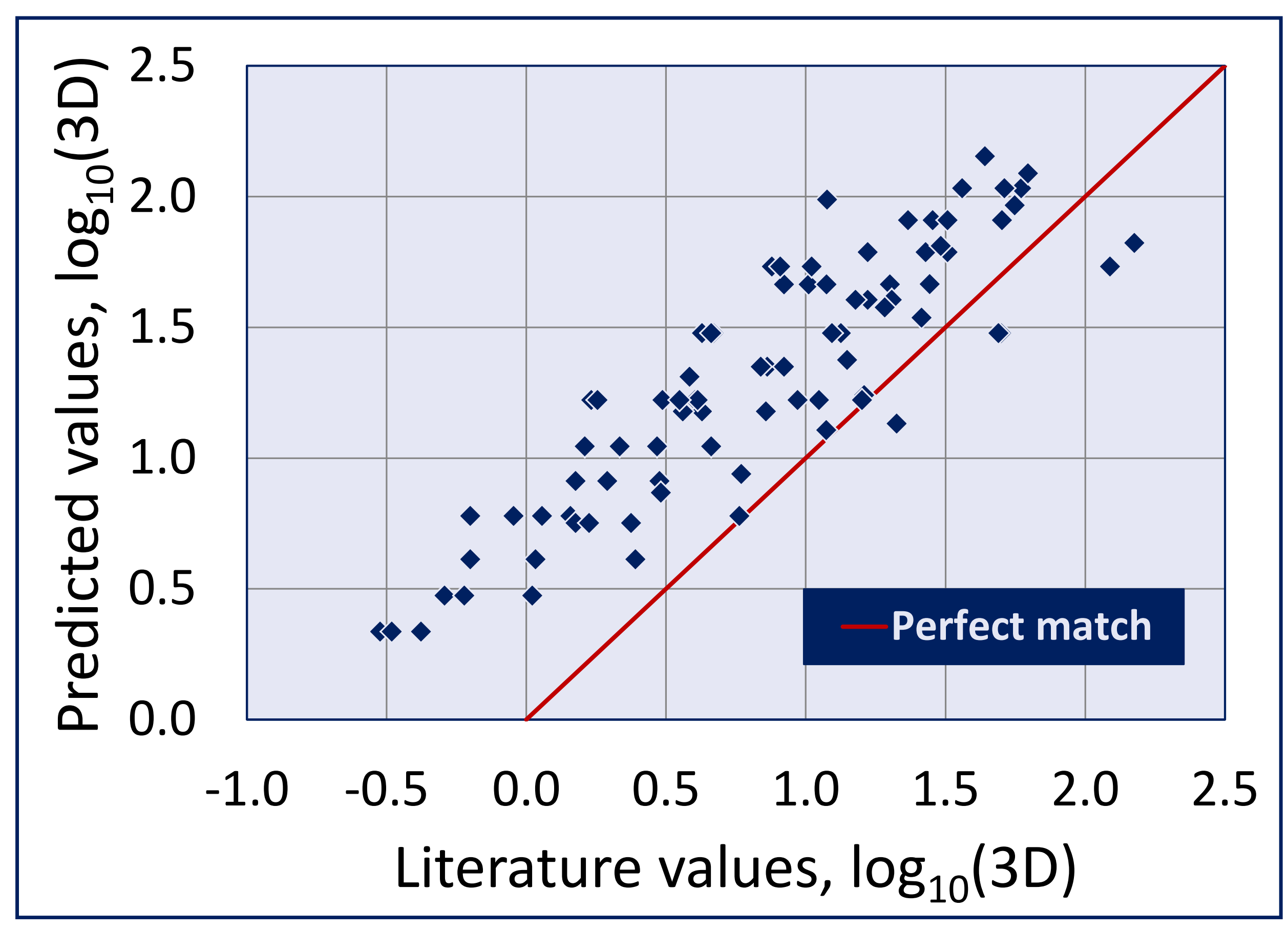

Figure 3. Validation - predicted values versus literature values of $\log _{10}(3 \mathrm{D})$ of $L$ isteria monocytogenes heated in meat and fish products.

\section{Methodology}

The work involved minced pork, chicken and salmon with different water phase salt (WPS) concentrations from 0 to $5.6 \%$ inoculated with latestationary phase L. monocytogenes cultures from three strains associated with fish, meat and industrial environment. Samples were vacuumpackaged in sterile bags, immerged in water bath, and held at constant temperatures from 57 to $65^{\circ} \mathrm{C}$.

\section{Modelling}

Heat tolerance was defined as the time to achieve 3 decimal reductions, i.e. 3D-values, by using both loglinear and non-linear-regression models (Figure 1). Development of a secondary predictive model describing the combined effect of temperature and WPS was carried out.

\begin{tabular}{ccccc} 
Temp. ${ }^{\circ} \mathrm{C}$ & WPS \% & $\begin{array}{c}\text { 3D log- } \\
\text { linear } \\
(\mathrm{min})\end{array}$ & $\begin{array}{c}\text { 3D } \\
\text { GInaFiT } \\
(\mathrm{min})\end{array}$ & $\begin{array}{c}\text { 3D F-test } \\
(\mathrm{min})\end{array}$ \\
\hline 57 & 0 & 41 & 46 & 43 \\
\hline 57 & 3.4 & 108 & 97 & 94 \\
\hline 57 & 4.9 & 151 & 154 & 144 \\
\hline 60 & 0 & 20 & 28 & 20 \\
\hline 60 & 3.4 & 22 & 23 & 23 \\
\hline 60 & 4.9 & 27 & 32 & 29 \\
\hline 65 & 0 & 3.8 & 4.4 & 4.4 \\
\hline 65 & 3.4 & 7.1 & 5.3 & 6.9 \\
\hline 65 & 4.9 & 8.6 & 8.2 & 8.7 \\
\hline RSS $-\log _{10}$ (3D) & 0.323 & 0.375 & 0.257 \\
Table 1. Heat tolerance of Listeria monocytogenes in pork products estimated using three
\end{tabular}

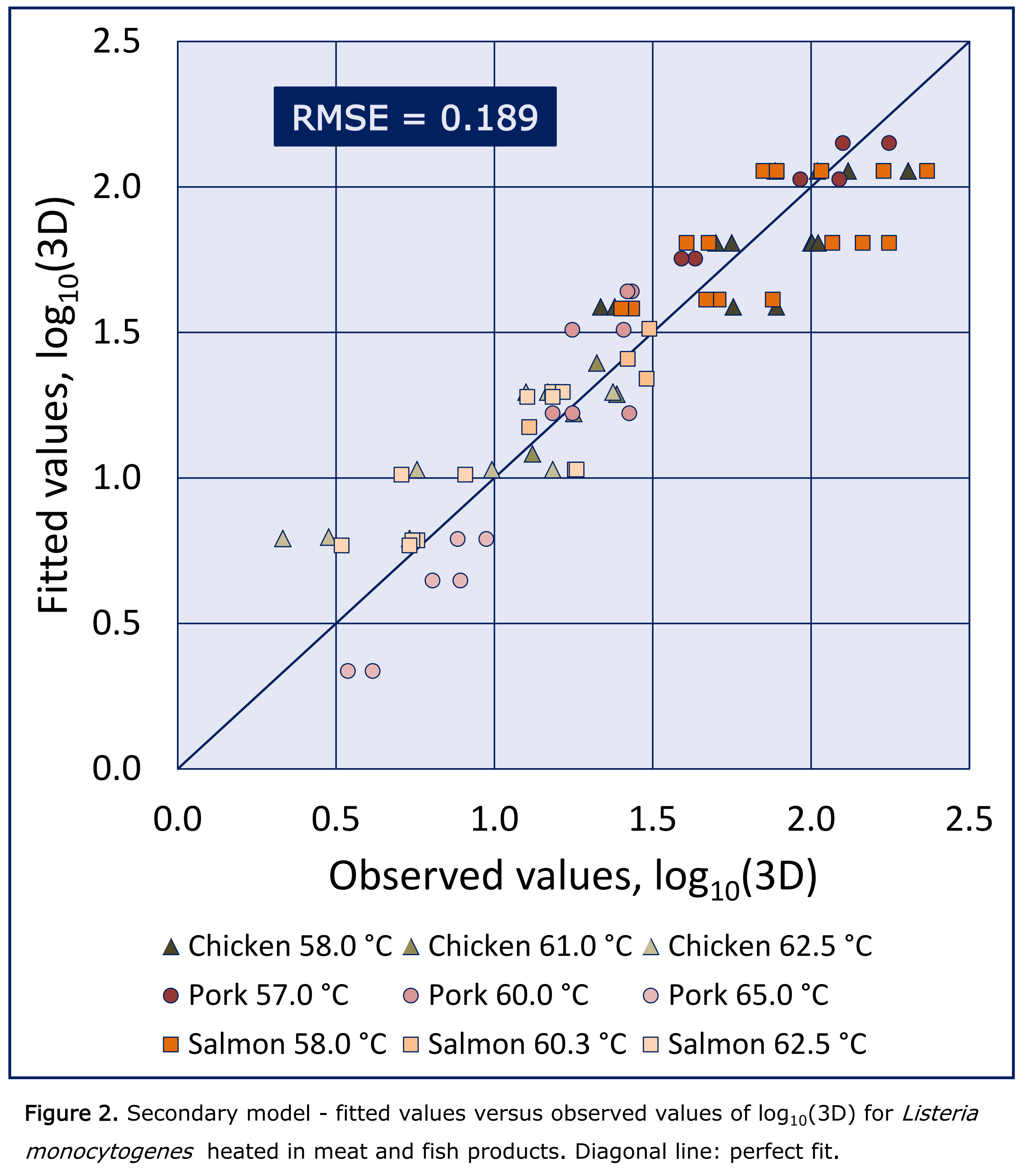

The mathematical structure of the model was adopted from Li et al. (Food Control 73:406, 2017):

$\log _{10}(3 \mathrm{D})=a+b \times$ Temp $+c \times$ Temp $\times$ WPS

Three different approaches i) Loglinear, ii) GInaFiT and iii) F-test were applied for selection of the 3D-values to be included as responses in the development of the model (Figure 1).

The F-test approach resulted in best fit (Table 1) with $a=11.8476, b=-0.1771$ and $c=0.00142$. Goodness-of-fit is shown in Figure 2.

\section{Validation}

The secondary model was validated using 86 external literature values from six different sources (Figure 3). WPS from 0 to $6 \%$, temperatures from 57.5 to $65.0^{\circ} \mathrm{C}$ and salmon roe, minced meat (beef and pork) and pork slurry were represented.

The bias and accuracy factors were 2.92 and 3.14 , respectively, when Dvalues were used as response. When $\log _{10}(3 D)$-values were used, the bias factor was 1.78 and the accuracy factor was 1.81 . 